\title{
Carbon dioxide sequestration of fly ash alkaline-based mortars containing recycled aggregates and reinforced by hemp fibres
}

\author{
M. Mastali a , Z. Abdollahnejad ${ }^{\text {a }}$, F. Pacheco-Torgal ${ }^{\mathrm{a}, \mathrm{b}, *}$ \\ ${ }^{a}$ C-TAC Research Centre, University of Minho, Guimarães, Portugal \\ ${ }^{\mathrm{b}}$ SHRC, University of Sungkyunkwan, Suwon, Republic of Korea
}

\section{H I G H L I G H T S}

- Mixture with $8 \%$ hemp fibres show a 50\% reduction in mechanical properties.

- Accelerated carbonation leads to a carbon sequestration of $-102 \mathrm{kgCO} 2 \mathrm{eq} / \mathrm{m}^{3}$.

- Mixture without hemp fibres show a carbon footprint of $38 \mathrm{kgCO}_{2} \mathrm{eq} / \mathrm{m}^{3}$.

- The use of $8 \%$ hemp fibre has a negative global warming potential of $-19.7 \mathrm{kgCO}{ }_{2} \mathrm{eq} / \mathrm{m}^{3}$.

\section{A R T I C L E I N F O}

\section{Article history:}

Received 26 June 2017

Received in revised form 29 September

2017

Accepted 10 November 2017

\section{Keywords:}

Carbon dioxide sequestration

Fly ash

Recycled aggregates

Hemp fibres

Alkali-activated mortars

\begin{abstract}
A B S T R A C T
Carbon dioxide sequestration is crucial for targets for limiting global warming could be achieved. This paper discloses results of an investigation concerning the performance of fly ash/waste glass alkalinebased mortars with recycled aggregates reinforced by hemp fibres exposed to accelerated carbon dioxide curing. Compressive strength, freeze-thaw resistance, carbon footprint and cost were studied. The results show that hemp fibres lead to a reduction of mechanical properties of alkali-activated materials. A high correlation was found between compressive and flexural strength. The results also show that accelerated curing provides a high carbon sequestration. Furthermore, the use of at least $8 \%$ hemp fibres leads to carbon negative emissions $-19.7 \mathrm{kgCO}{ }_{2} \mathrm{eq} / \mathrm{m}^{3}$ for fly ash/waste glass alkaline-based mortars with recycled aggregates based composites.
\end{abstract}

(c) 2017 Elsevier Ltd. All rights reserved.

\section{Introduction}

2016 was the first year with atmospheric $\mathrm{CO}_{2}$ concentrations above $400 \mathrm{ppm}$ all year round [11]. This means that the $350 \mathrm{ppm}$ boundary set in the [27] global sustainability model was already crossed risking "abrupt environmental change within continentalto planetary-scale systems". Therefore, some authors [16] state that carbon dioxide sequestration is crucial so targets for limiting global warming can be achieved. That is why carbon sequestration constitutes one of the Grande Challenges of Engineering [20]. Currently this carbon sequestration is carried out mostly through geologic $\mathrm{CO}_{2}$ storage in saline aquifers [34]. However, that constitutes a passive strategy has large risks and also has a very high cost. Carbon capture and storage (CCS) from the stream of concentrated $\mathrm{CO}_{2}$ at fossil fuel burning sites like power plants or steel plants is more

\footnotetext{
* Corresponding author at: C-TAC Research Centre, University of Minho, Guimarães, Portugal.

E-mail address: torgal@civil.uminho.pt (F. Pacheco-Torgal).
}

efficient and thus less expensive than direct air capture [16]. As a consequence it is important to study how $\mathrm{CO}_{2}$ generated by power plants and other facilities can be sequestrated in valuable products. Several authors $[10,17]$ have studied the use of $\mathrm{CO}_{2}$ as accelerated curing of cementitious constructions materials. This technology will in future prevent carbon dioxide to be released into the atmosphere but also to accelerate curing and strength development of those materials. However, so far no studies were performed using alkali activated based materials. These materials are produced though the reaction of an aluminosilicate powder with an alkaline activator, usually composed by hydroxide, silicate, carbonate or sulfate leading to the formation an amorphous aluminosilicate gel and secondary nano crystalline zeolite-like structures [26]. These materials have a particular ability for the reuse of several types of wastes [25,8]. Some wastes like fly ash deserve a especial attention because they are generated in a very high amount and have a very low reuse rate. USA has a reuse rate for fly ash of around 50\% meaning that 30 million tons of fly ash are not reused annually [3]. Waste glass is also a waste that is generated in 
relevant quantities and that merits increase recycling efforts. In 2010 , approximately 425,000 tons of waste glass was produced in Portugal and only 192,000 tons were recycled. In Hong Kong, approximately 373 tons of waste glass is generated daily in 2010 . The high volume of construction and demolition wastes (CDW) also constitutes a serious problem. Eurostat estimates the total for Europe of around 1000 million tons/year, representing an average value of almost 2.0 ton/per capita. The reuse of CDW as recycled aggregates not only constitutes a way to give value to a waste but also prevents the use of river sand being necessary to achieve the 70\% target until 2020 in EU [23]. Furthermore, the use of cementitious building materials reinforced with natural fibres could be a way to achieve a more sustainable construction. Natural fibres are a renewable resource and are available almost all over the world. Vegetable fibres cement based composites are as stronger as composites based on synthetic fibres, cost-effective and above all environmental friendly [24]. Moreover, their environmental impact is lower than traditional building materials because relatively large amounts of atmospheric $\mathrm{CO}_{2}$ can be sequestrated through photosynthesis [30]. Among the new vegetable fibres used, hemp stands out from the rest because of its wide availability, low requirements of fertilizer and irrigation, good humidity control and favourable energy and ecological balances [33]. That is why research on cement composites reinforced by natural fibres constitute an important trend in the sustainability context [21]. Natural fibres can degrade in high alkaline environment of Portland cement composites [15]. However, several authors [2,32], showed that carbonation is associated to a lower alkalinity that can help preserve both the properties and durability of composites reinforced with natural fibres. This means that accelerated carbonation of composites reinforced with natural fibres has not only carbon sequestration advantages but is also especially indicated for such composites. This paper discloses results of an investigation concerning the performance of fly ash/waste glass alkaline-based mortars with recycled aggregates reinforced by hemp fibres exposed to accelerated carbon dioxide curing.

\section{Experimental program}

\subsection{Materials}

The mortars were made of fly ash (FA), calcium hydroxide $(\mathrm{CH})$, waste glass (MG), ordinary Portland cement (OPC), recycled aggregates and a sodium hydroxide solution. The fly ash was obtained from The PEGO Thermal Power Plant in Portugal and categorized as class $\mathrm{B}$ and group $\mathrm{N}$ regarding the [5]. Table 1 presents the major oxides of fly ash particles. The Portland cement is of type I class $42.5 \mathrm{R}$ from SECIL, its composition contains $63.3 \% \mathrm{CaO}, 21.4 \% \mathrm{SiO}_{2}$, $4.0 \% \mathrm{Fe}_{2} \mathrm{O}, 3.3 \% \mathrm{Al}_{2} \mathrm{O}_{3}, 2.4 \% \mathrm{MgO}$ and other minor components. The calcium hydroxide was supplied by LUSICAL H100 and contain more than $99 \% \mathrm{CaO}$. Waste glass from glass bottles ground for one hour in a ball mill was also used. The final density of the milled waste glass was $1.27 \mathrm{~g} / \mathrm{cm}^{3}$. Solid sodium hydroxide was supplied by ERCROS, S.A., Spain, and was used to prepare the $8 \mathrm{M} \mathrm{NaOH}$ solution. Distilled water was used to dissolve the sodium hydroxide flakes to avoid the effect of unknown contaminants in the mixing water. The $\mathrm{NaOH}$ mix was made $24 \mathrm{~h}$ prior to use in order to have a homogenous solution at room temperature. A recycled sand to binder ratio of 4 was used in all the mixtures. The recycled sand was obtained from the crushing of concrete blocks. The average compressive strength of concrete blocks was around $40 \mathrm{MPa}$. A preliminary sieving operation was carried out to remove both coarser and dust particles before being used. The dimension of the sieves was $4.75 \mathrm{~mm}$ and $0.6 \mathrm{~mm}$. The sand was dried at $105^{\circ} \mathrm{C}$ for $24 \mathrm{~h}$ until constant mass achieved. After the preliminary sieving a standard sieving was carried out showing that the recycle sand has a fineness modulus of 3.885. The detailed grain size distribution of the recycled sand are presented in Fig. 1. The recycled sand has a water absorption by immersion of $13 \%$ having being determined with a $24 \mathrm{~h}$ saturation according to EN 1097-6. Before use the recycled sand was carbonated in a carbon chamber from Aralab model Fitoclima $\mathrm{S} 600\left(4.2 \% \mathrm{CO}_{2}, 40 \% \mathrm{RH}\right.$, and $\left.20^{\circ} \mathrm{C}\right)$ for $48 \mathrm{~h}$. The recycled sand has a water absorption of $25 \%$. The explanation for the increase of the water absorption relates to the fact that when $\mathrm{CSH}$ carbonates its $\mathrm{Ca} / \mathrm{Si}$ ratio drops and it becomes highly porous. Studies by NMR spectroscopy indicate that decomposition of $\mathrm{C}-\mathrm{S}-\mathrm{H}$ caused by carbonation involves two steps: 1) a gradual decalcification of the $\mathrm{C}-\mathrm{S}-\mathrm{H}$, where calcium is removed from the interlayer and defect sites in the silicate chains until $\mathrm{Ca} / \mathrm{Si}=0.67$ is reached, ideally corresponding to infinite silicate chains; 2) calcium from the principal layers is consumed, resulting in the final decomposition of the $\mathrm{C}-\mathrm{S}-\mathrm{H}$ and the formation of an amorphous silica phase [28]. The mortars were reinforced by different weight percentage of hemp shiv fibres that were supplied by Canapor. No surface treatment was used for the hemp shiv fibres in order to avoid cost increase and maintain its eco-effectiveness. Table 2 shows the composition of calcined hemp. The characterization of hemp shiv fibres was implemented based on a statistical analysis to evaluate the variability of the fibre length, which was defined by using 200 fibres. Regarding the statistical analysis, most fibre lengths varied in the range of $20-30 \mathrm{~mm}$ (Fig. 2).

\subsection{Mix design and mortar production}

The composition of the mortars is shown in Table 3. In the batching process of the mortars, dry ingredients (fly ash, recycled sand, calcium hydroxide (or cement), metakaolin, and milled glass) were mixed for $2 \mathrm{~min}$. Then, sodium hydroxide was added and again mixed for $3 \mathrm{~min}$. Finally the hemp fibres were added and all the ingredients were mixed for 3 more minutes. Then, the mixed mortars were cast into cubic molds $\left(50 \times 50 \times 50 \mathrm{~mm}^{3}\right)$ to assess the compressive strength and in prismatic beams with dimension $(40 \times 40 \times 160 \mathrm{~mm})$ to assess the flexural strength. The specimens were cured for $24 \mathrm{~h}$ at the lab conditions (averagely $25^{\circ} \mathrm{C}$ and $40 \% \mathrm{RH}$ ) and then they were demolded. Then the specimens were cured in the carbonation chamber $\left(4.2 \% \mathrm{CO}_{2}\right.$ concentration and $40 \% \mathrm{RH}$ ) for 7 days and curing in the lab conditions for the remaining days until the age of the test. This is because preliminary experiments showed that all mixtures were fully carbonated during 7 days through a $\mathrm{CO}_{2}$ preconditioning curing. Three specimens with dimension of $50 \times 50 \times 50 \mathrm{~mm}^{3}$ were casted and used to measure the $\mathrm{CO}_{2}$ sequestration in the mixture without hemp fibres by using a furnace decomposition method [13]. The carbonated specimens were placed initially in the oven at $105{ }^{\circ} \mathrm{C}$ during $24 \mathrm{~h}$ to evaporate any absorbed water. Then, the weights of the

Table 1

Chemical composition of major oxides in fly ash.

\begin{tabular}{|c|c|c|c|c|c|c|c|c|}
\hline \multirow[t]{2}{*}{ Material } & \multicolumn{8}{|c|}{ Oxides (wt\%) } \\
\hline & $\mathrm{SiO}_{2}$ & $\mathrm{Al}_{2} \mathrm{O}_{3}$ & $\mathrm{Fe}_{2} \mathrm{O}_{3}$ & $\mathrm{CaO}$ & $\mathrm{MgO}$ & $\mathrm{Na}_{2} \mathrm{O}$ & $\mathrm{K}_{2} \mathrm{O}$ & $\mathrm{TiO}_{2}$ \\
\hline Fly ash & 60.81 & 22.68 & 7.64 & 1.01 & 2.24 & 1.45 & 2.70 & 1.46 \\
\hline
\end{tabular}




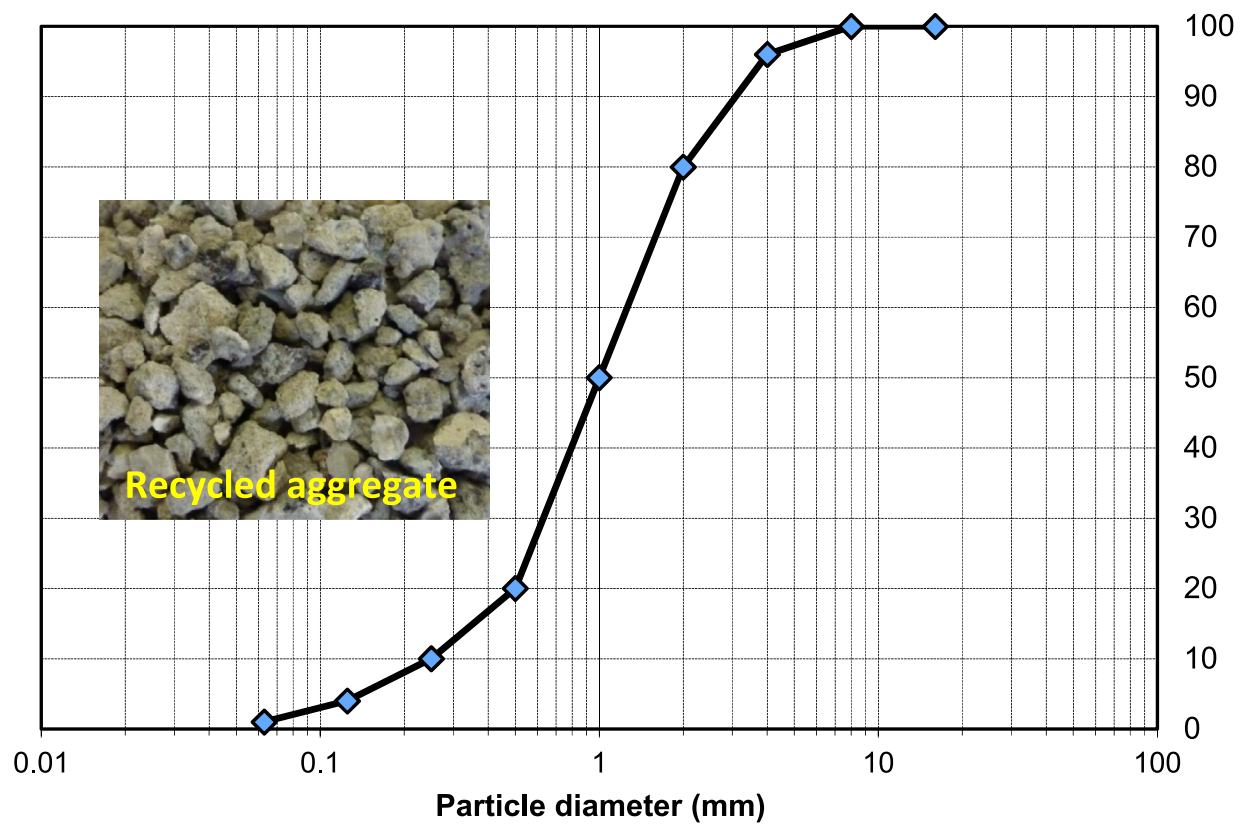

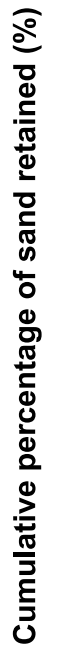

Table 2

Chemical composition of major oxides in calcined hemp.

\begin{tabular}{|c|c|c|c|c|c|c|c|c|}
\hline \multirow[t]{2}{*}{ Material } & \multicolumn{8}{|c|}{ Oxides (wt\%) } \\
\hline & $\mathrm{SiO}_{2}$ & $\mathrm{SO}_{3}$ & $\mathrm{P}_{2} \mathrm{O}_{5}$ & $\mathrm{CaO}$ & $\mathrm{Fe}_{2} \mathrm{O}_{3}$ & $\mathrm{Na}_{2} \mathrm{O}$ & $\mathrm{K}_{2} \mathrm{O}$ & $\mathrm{Mg}$ \\
\hline Calcined hemp & 24.6 & 4.60 & 3.0 & 44.0 & 0.78 & 9.78 & 12.10 & 0.40 \\
\hline
\end{tabular}

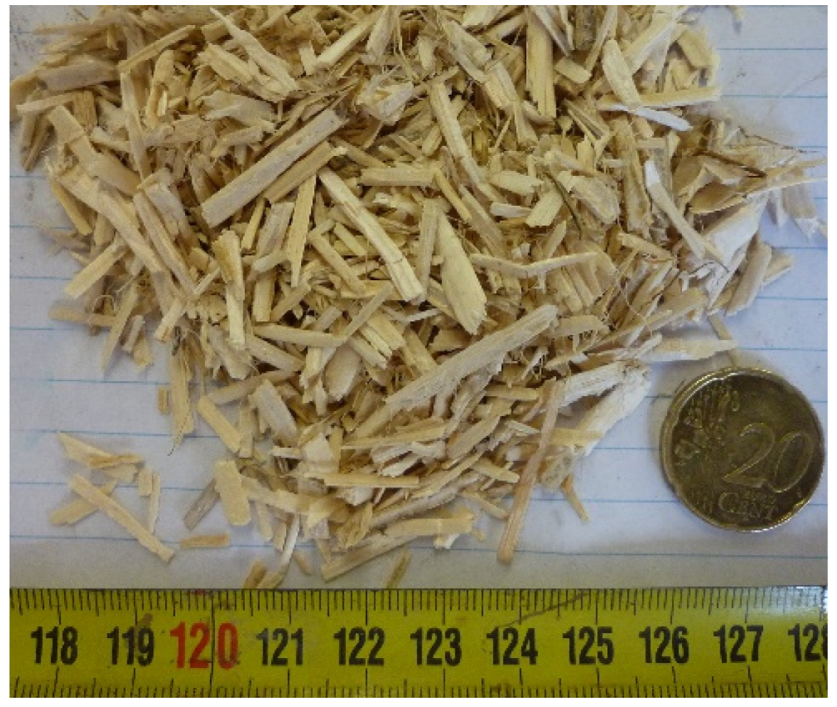

Fig. 2. Hemp shiv fibres. dried specimens were recorded. Afterwards, the specimens were put in the calciner at a temperature between $500-850{ }^{\circ} \mathrm{C}$ during $4 \mathrm{~h}$ to measure the water bound to hydration products and carbon dioxide in carbonates. The results revealed that $800^{\circ} \mathrm{C}$ could be used as the appropriate decomposition temperature. The compressive strengths of the mixtures were assessed at different ages 7, 14, and 28 days. The compressive strength of each mixture was obtained by averaging the replicated three cubes. All cubic specimens were assessed under compressive load with a constant displacement rate of $0.30 \mathrm{~N} / \mathrm{mm}^{2}$.s, based on the [6] recommendation. The compressive load was measured with a load cell of 200 kN capacity. Flexural performance was assessed under Three Point Bending (TPB) load conditions, as indicated in Fig. 3. The flexural load was applied to the beams with a displacement rate of 0.6 $\mathrm{mm} / \mathrm{min}$. The flexural load was measured with a load cell of 50 $\mathrm{kN}$ capacity. Eq. (1) was used to calculate the flexural strength of specimens under TPB test:

$\sigma_{f}=\frac{3 F L}{2 b h^{2}}$

Table 3

Proportions of mix compositions $\left(\mathrm{kg} / \mathrm{m}^{3}\right)$.

\begin{tabular}{|c|c|c|c|c|c|c|c|}
\hline Mixtures & Fly ash & $\mathrm{CH}$ & MG & $\mathrm{SH}$ & Sand & Molarity (mol/L) & Hemp fibre \\
\hline 80FA_10CH_10MG_RAGC_8M_0\% & 340.0 & 42.5 & 42.5 & 215.5 & 1700.0 & 8 & 0.0 \\
\hline 80FA_10CH_10MG_RAGC_8M_4\% & & & & & & & 17.0 \\
\hline 80FA_10CH_10MG_RAGC_8M_6\% & & & & & & & 25.5 \\
\hline 80FA_10CH_10MG_RAGC_8M_8\% & & & & & & & 34.0 \\
\hline
\end{tabular}

FA-Fly ash, CH-Calcium hydroxide, MG-Milled glass, SH-sodium hydroxide. 

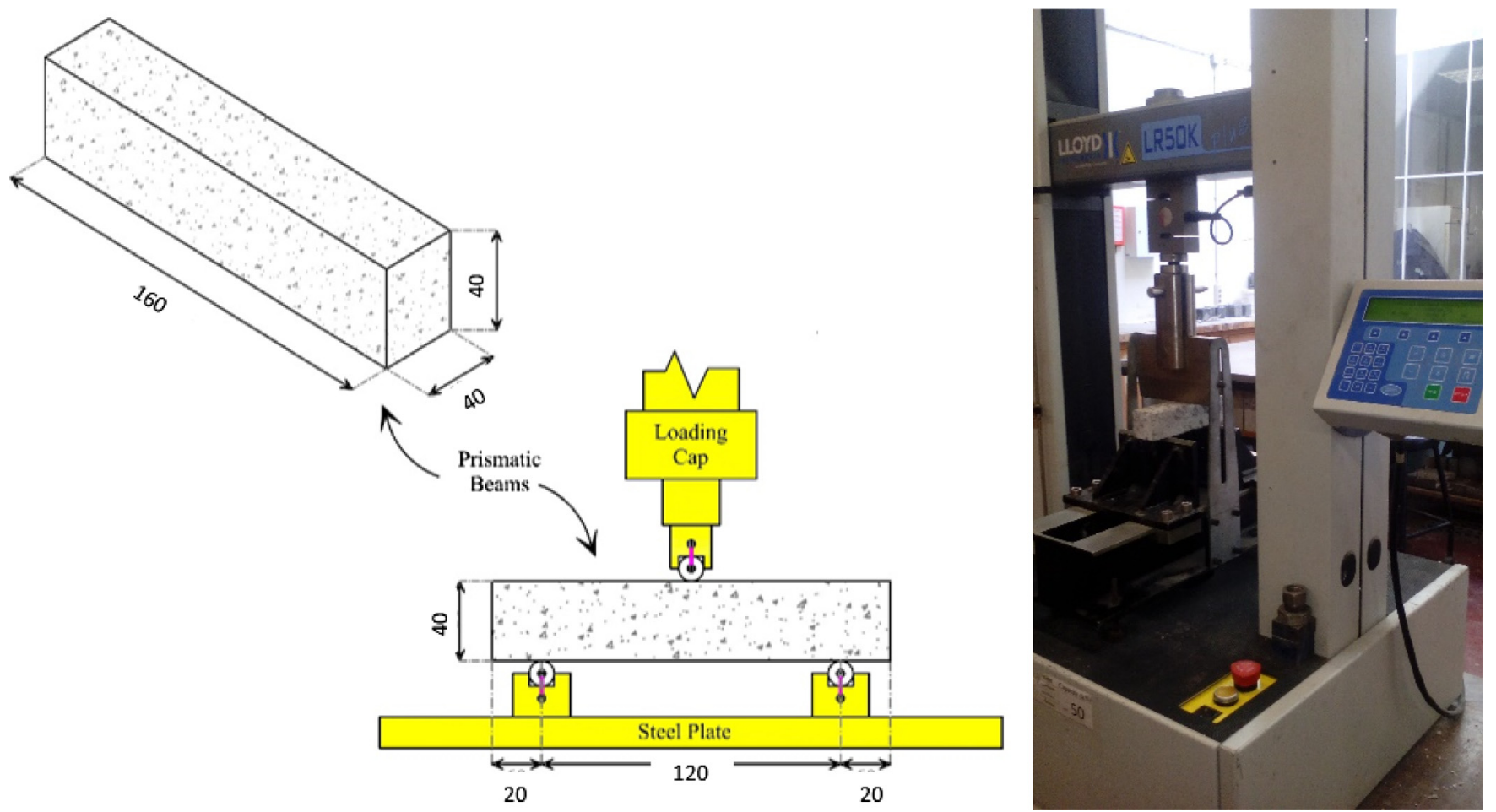

Fig. 3. Adopted test setup for implementation of the flexural test.

where, $\mathrm{F}$ is the total flexural load, $\mathrm{L}$ is span length, $\mathrm{b}$ and $\mathrm{h}$ are width $(40 \mathrm{~mm})$ and height $(40 \mathrm{~mm})$ of beams, respectively. Freeze/thaw resistance was assessed using three cubic specimens per mixture with dimension $100 \times 100 \times 100 \mathrm{~mm}$ were cast and tested after 28 days under compressive test. The equipment for freeze-thaw is Aralab model Fitoclima 1000. The freeze-thaw test was carried out according to PD CEN/TS 12390-9:2016 standard with temperatures are ranged from $-18^{\circ} \mathrm{C}$ to $+20^{\circ} \mathrm{C}$. The specimens were keep $13 \mathrm{~h}$ in $-18^{\circ} \mathrm{C}$ and $3 \mathrm{~h}$ in $+20^{\circ} \mathrm{C}$. The transitions from positive to negative and negative to positive temperatures took $3 \mathrm{~h}$ and $5 \mathrm{~h}$, respectively. The specimens were submitted to 50 freeze-thaw cycles. Fig. 4 shows a standard cycle.

\section{Results and discussion}

\subsection{Compressive strength}

Fig. 5 shows the effects of different hemp shiv fibre contents on the compressive strength of fly ash based alkaline mortars accord-

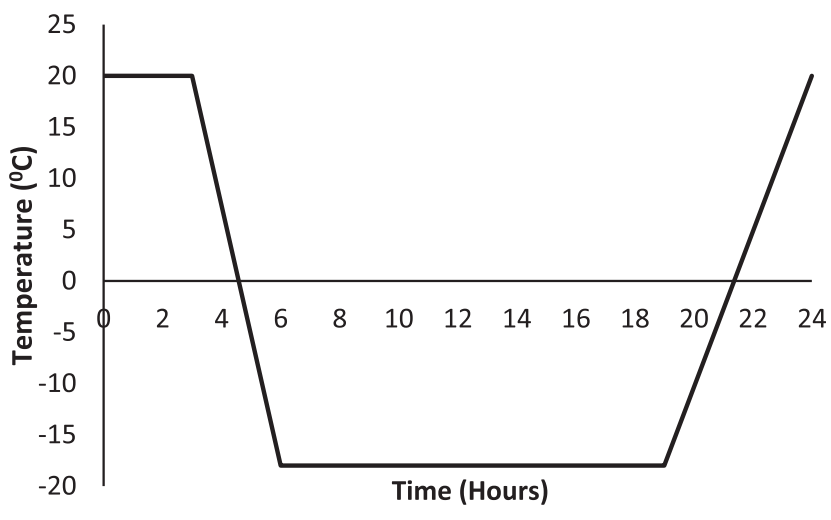

Fig. 4. Temperature variation for one freeze/thaw cycle. ing to curing age. At seven days the reference mixture without fibres shows a compressive strength of about $7 \mathrm{MPa}$. This compressive strength level is lower for a structural applications but is enough for masonry units. The use of accelerated carbonation makes $\mathrm{CO}_{2}$ to diffuse through the pore network of the material, dissolving in the pore solution to form $\mathrm{HCO}_{3}^{-}$. This anion is a weak acid, that will reacts with calcium-rich hydration products promoting the formation of calcium carbonates through a decalcification process [9]. The main calcium rich hydration prodict being $\mathrm{C}-\mathrm{S}-$ $\mathrm{H}$ because this study used a low sodium hydroxide concentration [14]. The results show that the addition of hemp fibres leads to a reduction of compressive strength because fibres increases the porosity. This was also confirmed by other authors that studied the performance of composites containing hemp fibres [18]. For a hemp fibre content of $4 \%$ a $20 \%$ reduction on compressive strength is noticed while for a $8 \%$ fibre content a $45 \%$ reduction on compressive strength is noticed. At 14 curing days the reference mixture shows an increase of compressive strength of around 9 MPa representing a 30\% increase concerning 7 days curing. From 14 curing to 28 curing days a $10 \%$ increase in compressive strength was also noticed. At 28 curing days the strength loss remains at $20 \%$ when $4 \%$ hemp fibres are used. However, the use of a hemp fibre content of $8 \%$ shows a low compressive strength when compared to 7 days curing it increased only $10 \%$ in compressive strength. It seems that a certain amount of hemp fibres can prevent the hydration products to become denser. Sedan et al [29] has reported that pectin can in fact fix calcium preventing the formation of CSH. Some studies show that hemp fibres have a pectin content of around 7.9\% [7]. Recent studies [12]also confirm that hemp fibres act as retarding agents and reducing compressive and flexural strength. The results of the present investigation show that $6 \%$ hemp fibre is the maximum content for masonry applications. Valle-Zermeño et al. also investigated the mechanical properties of magnesium phosphate cements reinforced with hemp fibre. Hemp fibre with $8 \%, 12 \%$, $16 \%$, and $20 \%$ total weight of dry ingredient. For a hemp fibre content of $8 \%$ they noticed a severe compressive strength reduction of 


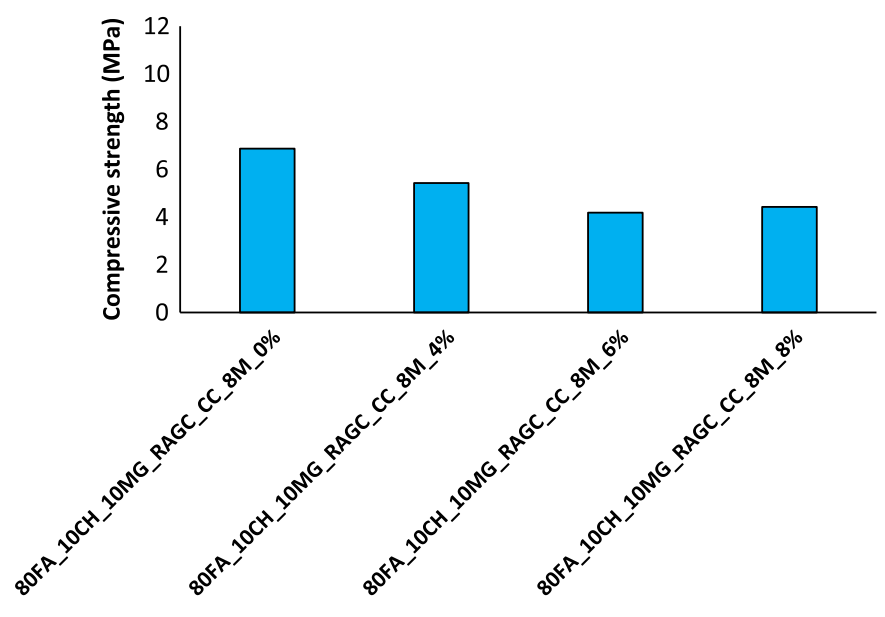

a)

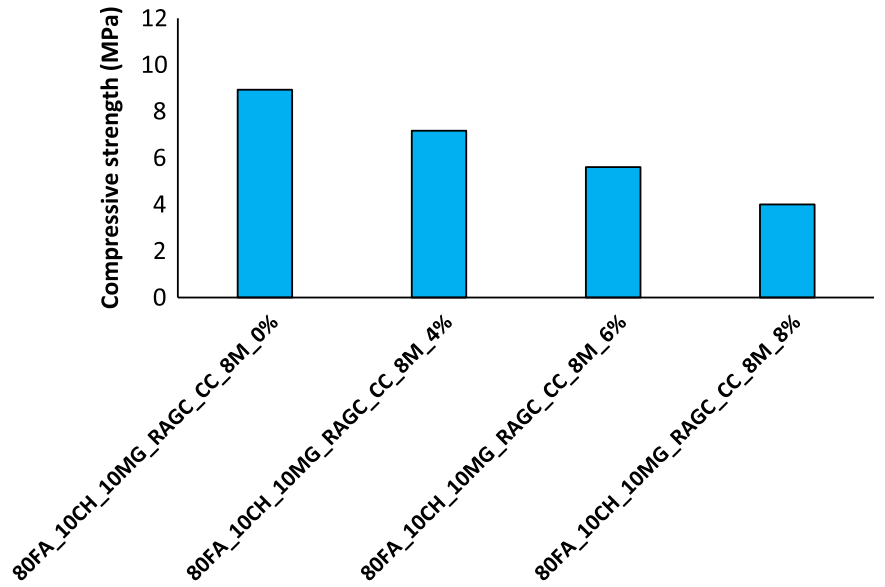

b)

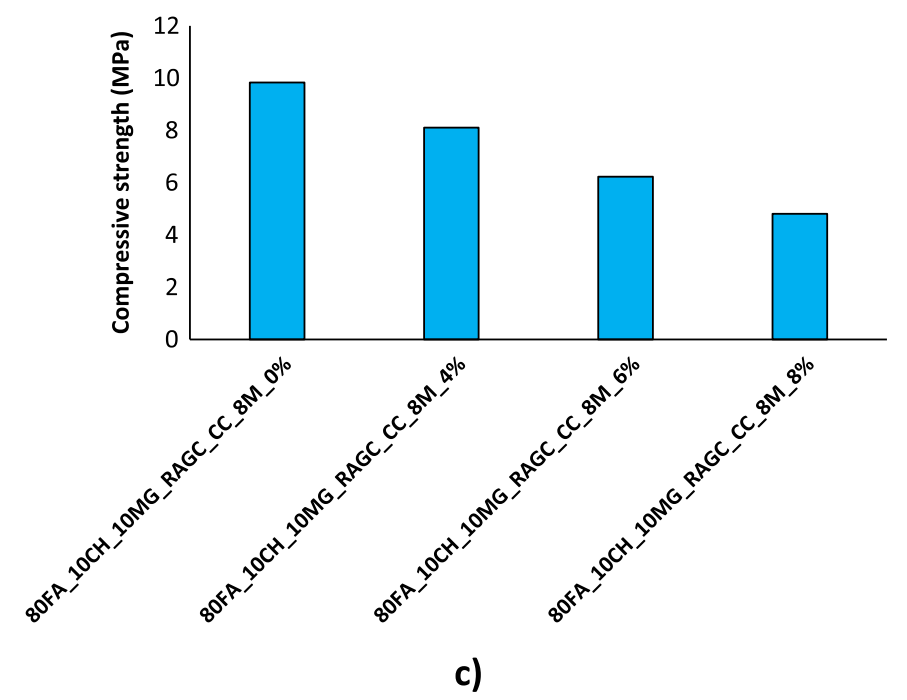

Fig. 5. Compressive strength of mixtures cured for: a) 7 days; b) 14 days; c) 28 days.

from $30 \mathrm{MPa}$ to just $10 \mathrm{MPa}$ after 1 curing days and from $45 \mathrm{MPa}$ to $12 \mathrm{MPa}$ at 28 days. This severe reduction on compressive strength maybe related to the fact that the high alkaline environment of the mixtures may have degrade the structure of the fibres.

\subsection{Flexural strength}

Fig. 6 shows the effects of reinforcing fly ash alkaline-based mortars containing recycled aggregates with hemp shiv fibres at 28 curing days. Regarding the results, addition of fibres consistently reduced the flexural strength due to non-homogeneous mix and, consequently, a poor adhesion between the fibres and the matrix. The use of just $4 \%$ of hemp fibres leads to flexural strength loss of about $25 \%$. The maximum reduction in the flexural strength due to the addition of fibre was detected bout $40 \%$ in the mixture contain $8 \%$ hemp fibre $(2.13 \mathrm{MPa})$, as compared to the plain mixture (3.45 MPa). Fig. 7 shows relevant correlations between the mechanical properties and the hemp fibre content. $\mathrm{F}_{\mathrm{r}}$ denotes the flexural strength and $\mathrm{W}_{\mathrm{f}}$ is the weight of hemp fibre. A high correlation $\left(R^{2}=0.86\right)$ between compressive strength and flexural strength is noticed. A higher negative correlation $\left(\mathrm{R}^{2}=\right.$ 0.97 ) was found between compressive strength and hemp fibre content.

\subsection{Resistance to freeze-thaw}

Fig. 8 shows the results of compressive strength of reference mixtures cured at ambient temperature and the compressive strength of mixtures after 50 cycles of freeze/thaw. The results show that the mixtures with fibre content show a lower frost resistance when compared to the mixture without fibees. After 50 cycles of freeze/thaw the mixture with no fibre show a compressive strength loss of just $10 \%$ while the mixtures with fibres show a compressive reduction of around $18 \%$. The fibre content show not have a direct influence regarding frost resistance. When water freezes in the pores of the matrix, an expansion in the volume of frozen water occurs, forcing the amount of excess water through the boundaries. The magnitude of this hydraulic pressure depends on the permeability of the matrix, the degree of saturation, the distance to the nearest unfilled void, and the rate of freezing, so that this hydraulic pressure exceeds the tensile strength of the paste, it forms the cracks. Further freezing cycles, new cracks will be formed and the deterioration will proceed.

\subsection{Carbon footprint}

The global warming potential (GWP) of the different mixtures were calculated using the individual GWP values taken form the 

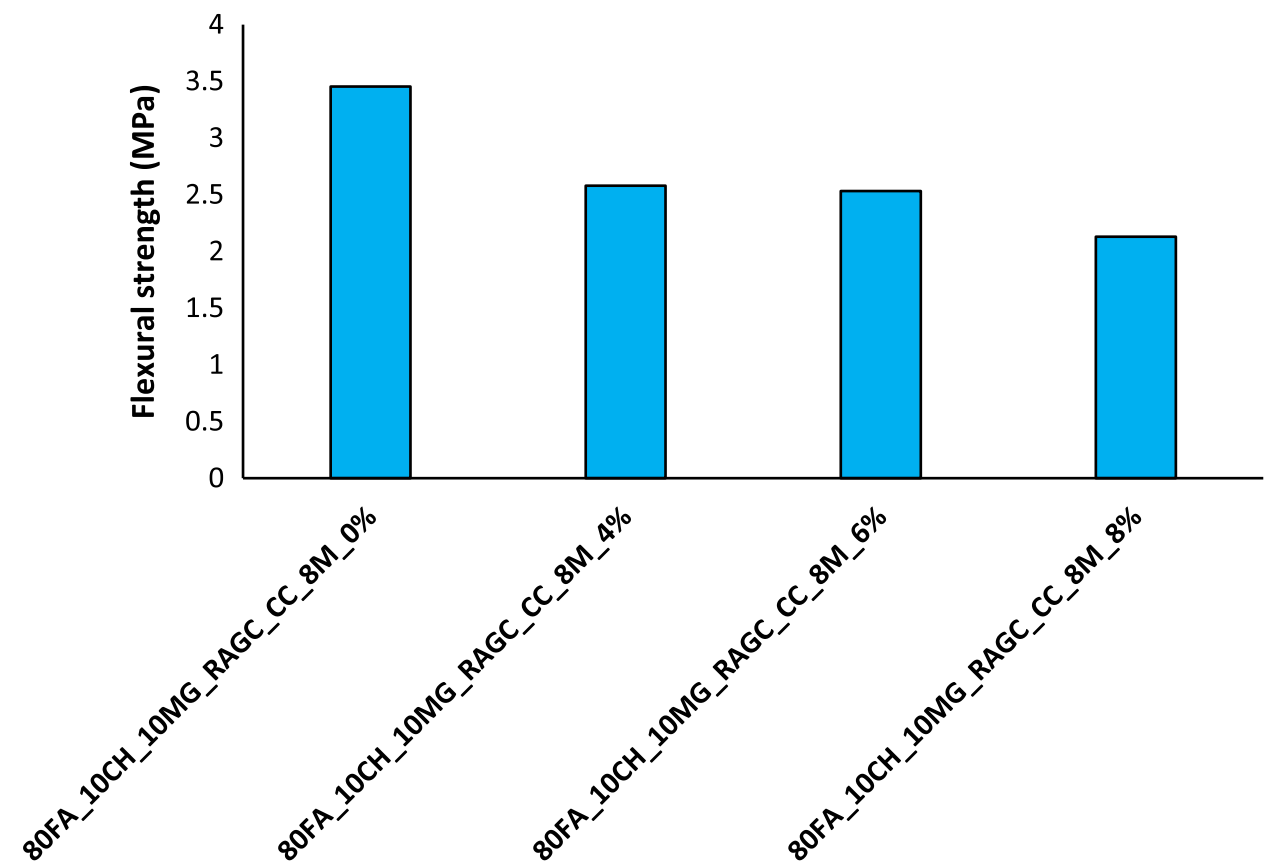

Fig. 6. Flexural strength.

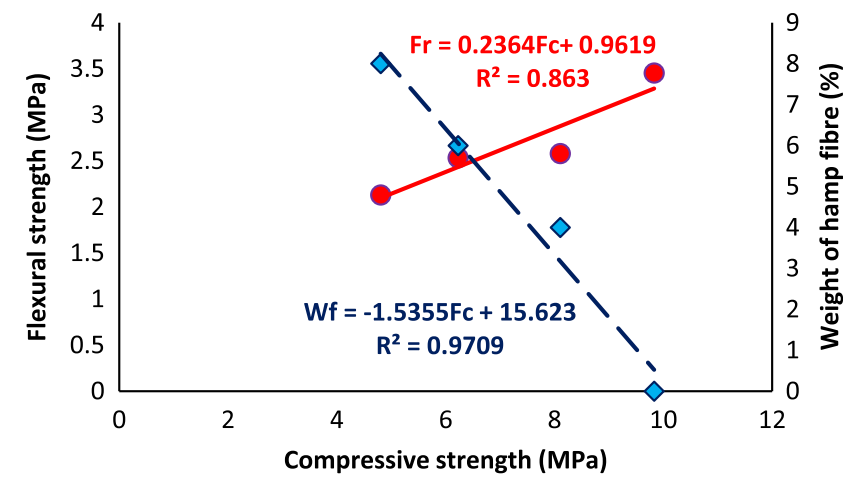

Fig. 7. Correlation between compressive strength, flexural strength, and hemp fibre content.
Ecoinvent database (Table 4). Details on the use of Ecoinvent database to estimate GWP on alkali-activated binders can be found in [22]. The exception being the negative GWP of hemp fibres that was taken from the recent work of [4] and that is explained by the biogenic $\mathrm{CO}_{2}$ uptake during hemp production. As to the carbon sequestration due to accelerated carbonation by using a furnace decomposition method it revealed a value of $-102 \mathrm{kgCO}{ }_{2} \mathrm{eq} / \mathrm{m}^{3}$. Fig. 9 shows the carbon footprint as well as the carbon sequestration. The results show that the carbon sequestration provided by the accelerated carbon curing has led to a carbon footprint of just $38 \mathrm{kgCO}_{2} \mathrm{eq} / \mathrm{m}^{3}$ for the mixtures without hemp fibres. [22] reported an embodied carbon of $227 \mathrm{kgCO}_{2} \mathrm{e} / \mathrm{m}^{3}$ for a mixture of hybrid cement based concrete. Also [1] reported global warming potential in range of $178 \mathrm{kgCO}_{2} \mathrm{e} / \mathrm{m}^{3}$ and $250 \mathrm{kgCO}_{2} \mathrm{e} / \mathrm{m}^{3}$ for

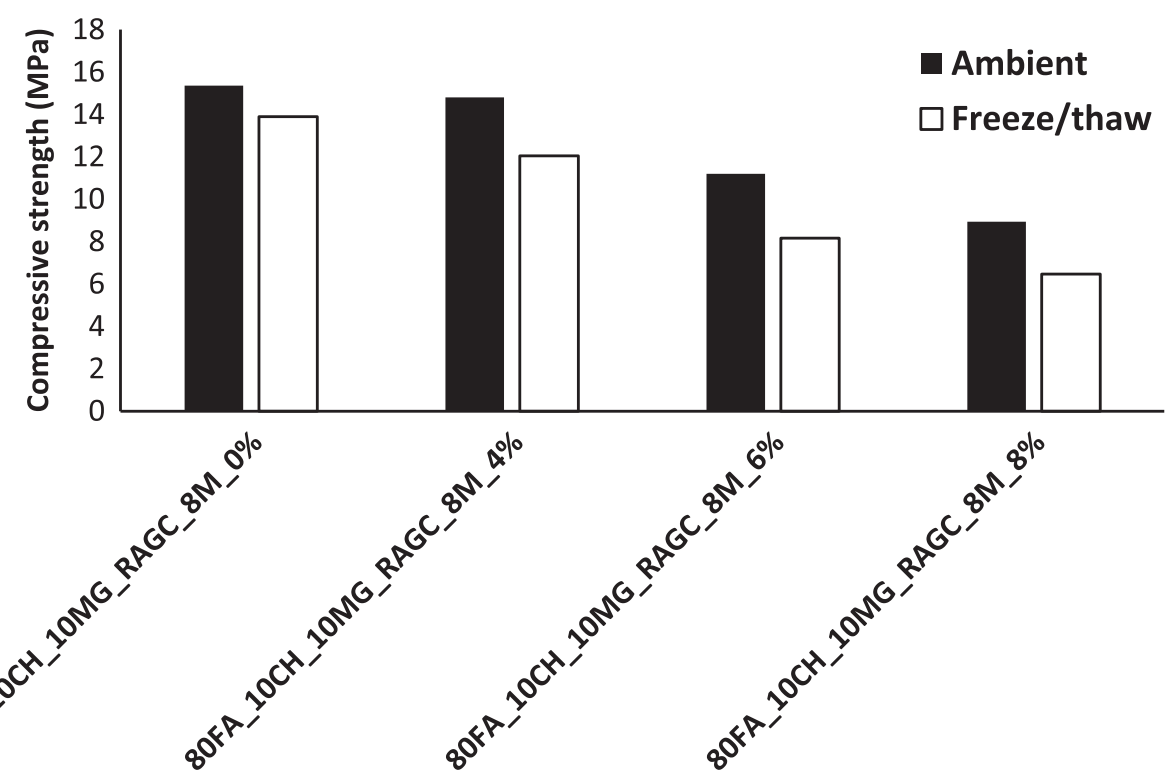

Fig. 8. Effects of freeze/thaw on the compressive strength. 
Table 4

Global warming potential (GWP) of each component of mixture $\left(\mathrm{kgCO}_{2} \mathrm{eq}\right)$.

\begin{tabular}{|c|c|c|c|c|c|c|c|}
\hline Recycled aggregates & MG & $\mathrm{CH}$ & Fly ash & Water & PC & $\mathrm{SH}$ & Hemp fibre \\
\hline 0.00401 & 0.00526 & 0.416 & 0.00526 & 0.000155 & 0.931 & 2.24 & $-1.70[4]$ \\
\hline
\end{tabular}
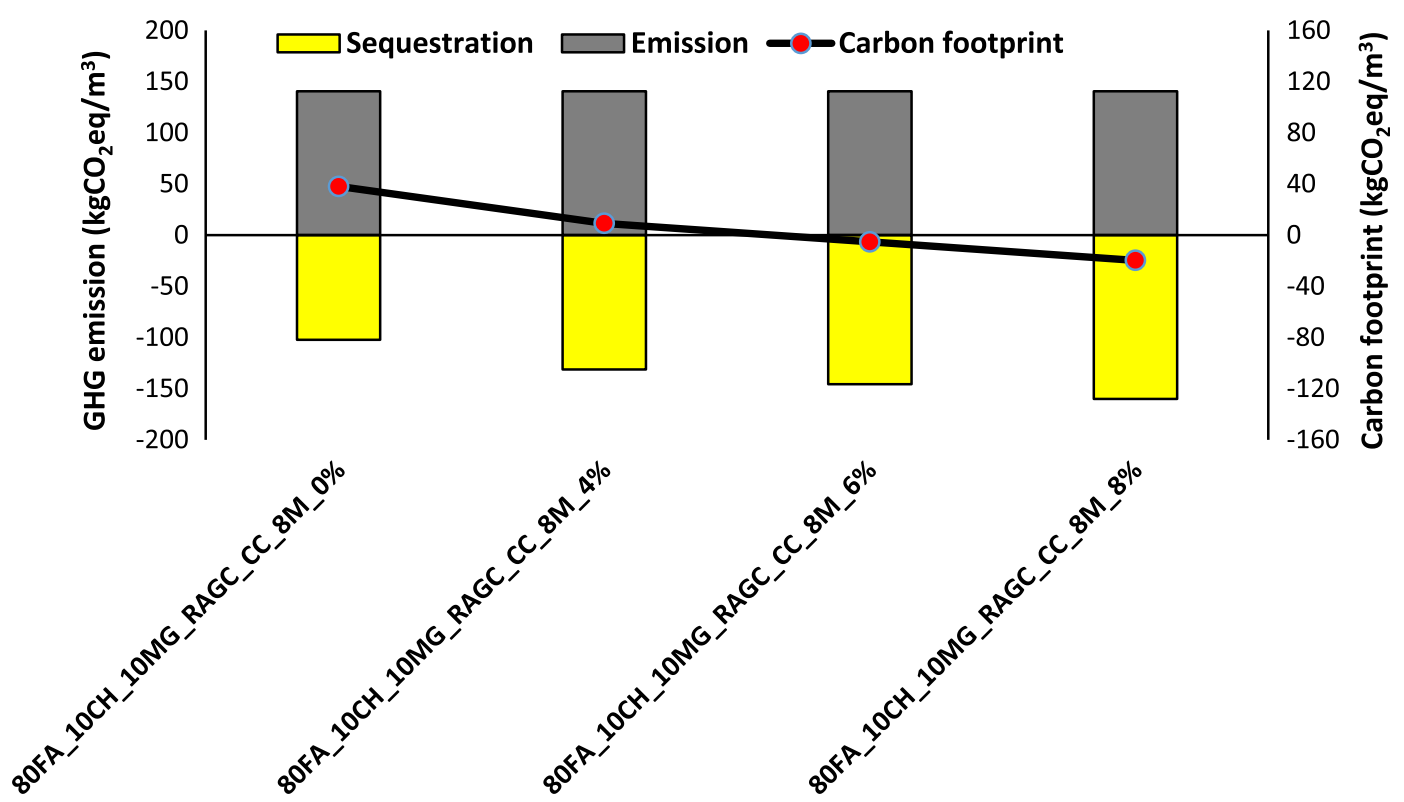

Fig. 9. GHG emission and carbon footprint of different mixtures.

Table 5

Costs of the materials (Euro/kg).

\begin{tabular}{|c|c|c|c|c|c|c|c|}
\hline Recycled aggregates & MG & $\mathrm{CH}$ & Fly ash & Water & PC & $\mathrm{SH}$ & Hemp fibre \\
\hline 0.047 & 0.009 & 0.283 & 0.03 & 0.01 & 0.1 & 0.85 & 0.52 \\
\hline
\end{tabular}
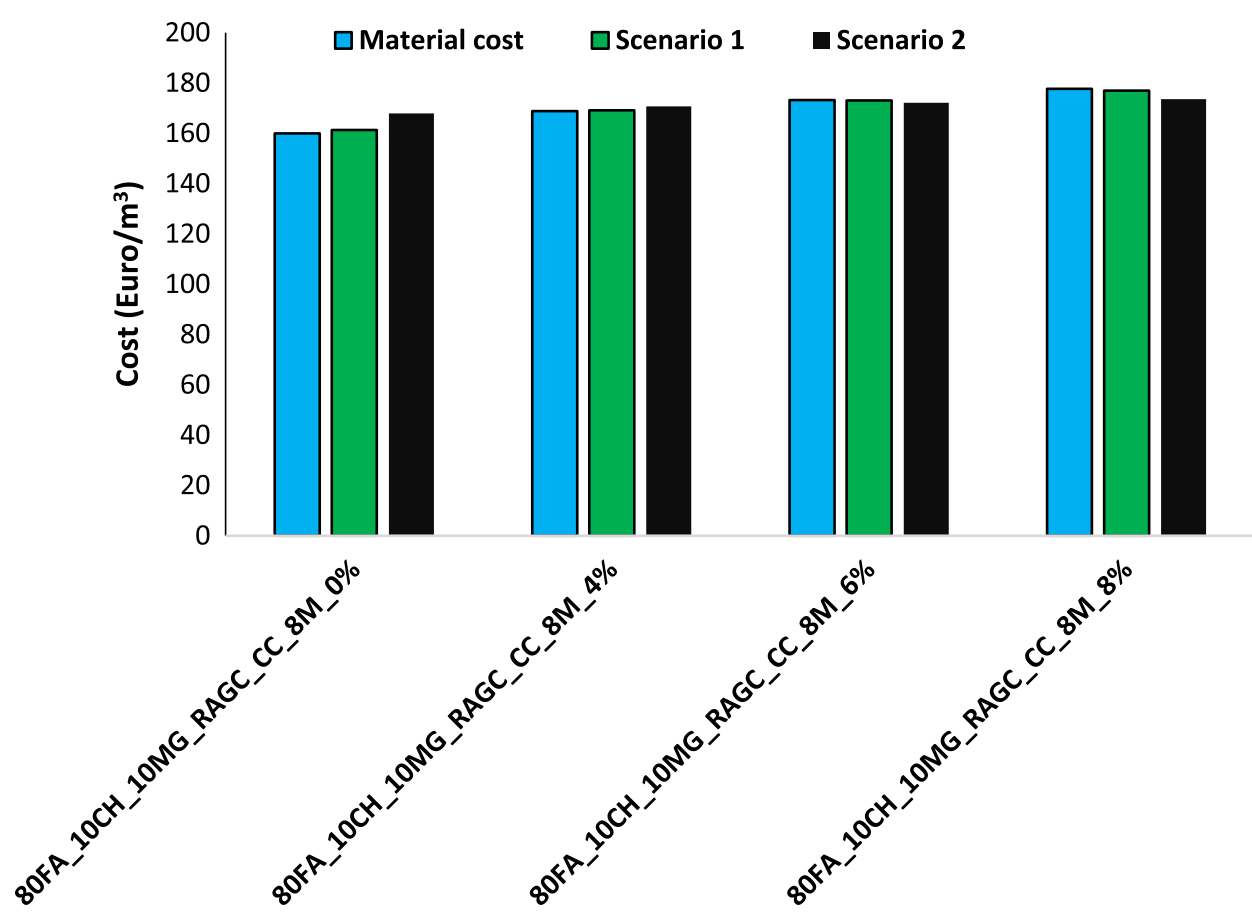

Fig. 10. Cost of the mixtures. 
one-part geopolymer foam mortars composed of fly ash, Ordinary Portland cement, calcined kaolin, sodium hydroxide and $\mathrm{Ca}(\mathrm{OH})_{2}$. Those results confirm the very promising performance of the mixtures developed in this study. The use of hemp fibres leads to a sustained increase of carbon sequestration and a reduction of carbon fooprint. Just using $6 \%$ hemp fibres leads to negative carbon dioxide fooprint $\left(-5.3 \mathrm{kgCO}_{2} \mathrm{eq} / \mathrm{m}^{3}\right.$ ). Mixtures with $8 \%$ hemp fibre content show a carbon fooprint of $-19.7 \mathrm{kgCO}{ }_{2} \mathrm{eq} / \mathrm{m}^{3}$.

\subsection{Cost analysis}

The construction industry has a very strong focus on cost and the fact that authors conducting studies on construction materials almost never address this issue this gap has been one of the causes that make the scientific community to develop materials that are never used due to cost restrictions. Furthermore, in a context of carbon sequestration its especially important to simulate how a future carbon tax will help favour products that have a high carbon sequestration potential. The cost of mixtures was calculated regarding the listed prices of mixture's ingredients in Table 5, which were provided by their suppliers. Moreover, two different scenarios were also assumed to consider a future carbon tax, including 1) 0.0347 Euro $/ \mathrm{kg}$ for the carbon footprint as the first [31]); 2) 0.206 Euro $/ \mathrm{kg}$ for considering the carbon footprint of mixtures as the second scenario [19]. Fig. 10 depicts the cost of the mixtures containing different masses of the hemp fibres. The mixture without hemp fibres has a cost of 160 euro $/ \mathrm{m}^{3}$. The hemp fibre addition leds to a slight increase in the cost of about $5 \%$ to a $4 \%$ fibre content. The results also show that use of a carbon tax has almost no influence at all in the cost of the mixtures with negative carbon footprint.

\section{Conclusions}

Compressive strength, and flexural strength were reduced by adding the hemp fibre, so that the maximum degradation in mechanical properties was found about $50 \%$ in the compressive strength due to addition of $8 \%$ hemp shiv fibre. The results show that $6 \%$ hemp fibre is the maximum content that allows a mechanical performance sufficient for masonry applications. A high correlation was found between compressive and flexural strength. A negative correlation was found between compressive strength and hemp fibre content. Accelerated carbonation showed a carbon sequestration of $-102 \mathrm{kgCO}_{2} \mathrm{eq} / \mathrm{m}^{3}$ and a carbon footprint of 38 $\mathrm{kgCO}_{2} \mathrm{eq} / \mathrm{m}^{3}$ for fly ash based alkaline mortars. Increasing the hemp fibre consistently increased the $\mathrm{CO}_{2}$ sequestration, so that the $\mathrm{CO}_{2}$ sequestration varied in the range of $-131 \mathrm{kgCO}_{2} \mathrm{eq} / \mathrm{m}^{3}$ to $-160 \mathrm{kgCO} 2 \mathrm{eq} / \mathrm{m}^{3}$. Addition of the hemp fibre continuously reduced the carbon footprint, so that the carbon footprint in the mixture reinforced with $8 \%$ hemp fibre is around $-19.7 \mathrm{kgCO}_{2} \mathrm{eq} /$ $\mathrm{m}^{3}$. The results show that use of a carbon tax has almost no influence at all in the cost of the mixtures with negative carbon footprint.

\section{Acknowledgment}

The authors would like to acknowledge the financial support of the Foundation for Science and Technology (FCT) in the frame of project IF/00706/2014-UM.2.15.

\section{References}

[1] Z. Abdollahnejad, S. Miraldo, F. Pacheco-Torgal, Aguiar J. Barroso, Cost-efficient one-part alkali-activated mortars with low global warming potential for floor heating systems applications", Eur. J. Environ. Civil Eng. 21 (2017) 412-429.
[2] V. Agopyan, H. Savastano, V. John, M. Cincotto, Developments on vegetable fibre-cement based materials in São Paulo, Brazil: an overview, Cem. Concr. Compos. 27 (2005) 527-536.

[3] American Coal Ash Association. https://www.acaa-usa.org/Publications/ Production-Use-Reports, 2016.

[4] A. Arrigoni, R. Pelosato, P. Melià, G. Ruggieri, S. Sabbadini, G. Dotelli, Life cycle assessment of natural building materials: the role of carbonation, mixture components and transport in the environmental impacts of hempcrete blocks, J. Cleaner Prod. 149 (2017) 1051-1061.

[5] ASTM C618-15, Standard Specification for Coal Fly Ash and Raw or Calcined Natural Pozzolan for Use in Concrete, ASTM International, West Conshohocken, PA, 2015.

[6] ASTM C109/C109M-16a, Standard Test Method for Compressive Strength of Hydraulic Cement Mortars (Using 2-in. or [50-mm] Cube Specimens), ASTM International, West Conshohocken, PA, 2016.

[7] G. Balčiūnas, I. Pundienè, L. Lekūnaitè-Lukošiūnè, S. Vejjelis, A. Korjakins, Impact of hemp shives aggregate mineralization on physical-mechanical properties and structure of composite with cementitious binding material, Ind. Crops Prod. 77 (2015) 724-734.

[8] S. Bernal, E. Rodríguez, A. Kirchheim, J. Provis, Management and valorisation of wastes through use in producing, alkali-activated. Cement materials, J. Chem. Technol. Biotechnol. (2016), https://doi.org/10.1002/jctb.4927.

[9] S. Bernal, Resistance to carbonation of alkali-activated materials, WoodHead Publishing Limited- Elsevier Science and Technology, Abington Hall, Cambridge, UK, 2014, pp. 319-332.

[10] M.F. Bertos, S.J.R. Simons, C.D. Hills, P.J. Carey, A review of accelerated carbonation technology in the treatment of cement-based materials and sequestration of CO 2, J. Hazard. Mater. 112 (3) (2004) 193-205.

[11] R. Betts, C. Jones, J. Knight, R. Keeling, J. Kennedy, El Niño and a record $\mathrm{CO}_{2}$ rise, Nat. Clim. Change 6 (2016) 806-810.

[12] Y. Diquélou, E. Gourlay, L. Arnaud, B. Kurek, Impact of hemp shiv on cement setting and hardening: influence of the extracted components from the aggregates and study of the interfaces with the inorganic matrix, Cem. Concr. Compos. 55 (2015) 112-121.

[13] H. El-Hassan, Y. Shao, Early carbonation curing of concrete masonry units with Portland limestone cement, Cement Concr. Compos. 62 (2015) 168177.

[14] I. Garcia-Lodeiro, S. Donatello, A. Fernandez-Jimenez, A. Palomo, Hydration of hybrid alkaline cement containing a very large proportion of fly ash: a descriptive model, Materials 9 (2016) 605.

[15] H. Gram, Durability of natural fibres in concrete, Swedish Cement and Concrete Research Institute, Stockolm, 1983.

[16] J. Hansen, M. Sato, P. Kharecha, K. von Schuckmann, D.J. Beerling, J. Cao, S. Marcott, V. Masson-Delmotte, M.J. Prather, E.J. Rohling. J. Shakun, P. Smith, Young people's burden: requirement of negative CO2 emissions, Earth Syst. Dynam. Discuss. (2017). arXiv preprint arXiv:1609.05878.

[17] J.G. Jang, G.M. Kim, H.J. Kim, H.K. Lee, Review on recent advances in $\mathrm{CO}_{2}$ utilization and sequestration technologies in cement-based materials, Constr. Build. Mater. 127 (2016) 762-773.

[18] Z. Li, X. Wang, L. Wang, Properties of hemp fibre reinforced concrete composites, Compos. Part A-Appl. S. 37 (3) (2006) 497-505.

[19] F. Moore, D. Diaz, Temperature impacts on economic growth warrant stringent mitigation policy", Nat. Clim. Change 5 (2015) 127-131.

[20] C. Mote, J. Dowling, J. Zhou, The power of an idea: the international impacts of the grand challenges for engineering, Engineering 2 (2016) 4-7.

[21] O. Onuaguluchi, N. Banthia, Plant-based natural fibre reinforced cement composites: a review, Cem. Concr. Compos. 68 (2016) 96-108.

[22] C. Ouellet-Plamondon, G. Habert, Life cycle analysis (LCA) of alkali-activated cements and concretes, in: F. Pacheco-Torgal, J. Labrincha, A. Palomo, C. Leonelli, P. Chindaprasirt (Eds.), Handbook of Alkali-Activated Cements, Mortars and Concretes, WoodHead Publishing-Elsevier, Cambridge, 2014, pp. 663-686.

[23] F. Pacheco-Torgal, V. Tam, J. Labrincha, Y. Ding, J. de Brito (Eds.), Handbook of recycled concrete and demolition waste, Elsevier, Cambridge, 2013.

[24] F. Pacheco-Torgal, S. Jalali, Cementitious building materials reinforced with vegetable fibres: a review, Constr. Build. Mater. 25 (2) (2011) 575-581.

[25] J. Payá, J. Monzó, M.V. Borrachero, M.M. Tashima, Reuse of aluminosilicate industrial waste materials in the production of alkali-activated concrete binders, WoddHead Publishing, Cambridge, UK, 2014, pp. 487-518.

[26] J.L. Provis, Geopolymers and other alkali activated materials: why, how, and what?, Mater Struct. 47 (2014) 11-25.

[27] J. Rockström, W. Steffen, K. Noone, Å. Persson, F.S. Chapin III, E. Lambin, T.M. Lenton, M. Scheffer, C. Folke, H. Schellnhuber, B. Nykvist, C.A. De Wit, T. Hughes, S. van der Leeuw, H. Rodhe, S. Sörlin, P.K. Snyder, R. Costanza, U. Svedin, M. Falkenmark, L. Karlberg, R.W. Corell, V.J. Fabry, J. Hansen, B. Walker, D. Liverman, K. Richardson, P. Crutzen, J. Foley, Planetary boundaries:exploring the safe operating space for humanity, Ecol. Soc. 14 (2) (2009) 32.

[28] Branko Šavija, Mladena Luković, Carbonation of cement paste: understanding, challenges, and opportunities, Constr. Build. Mater. 117 (2016) 285-301.

[29] D. Sedan, C. Pagnoux, A. Smith, T. Chotard, Mechanical properties of hemp fibre reinforced cement: influence of the fibre/matrix interaction, J. Eur. Ceram. 28 (2008) 183-192.

[30] A. Shea, M. Lawrence, P. Walker, Hygrothermal performance of an experimental hemp-lime building, Constr. Build. Mater. 36 (2012) 270275. 
[31] Stanford Report, Estimated social cost of climate change not accurate, Stanford scientists say", Retrieved from http://news.stanford.edu/news/2015/january/ emissions-social-costs-011215.html (Date of access: 14.06.2017).

[32] G. Tonoli, S. Santos, A. Joaquim, H. Savastano, Effect of accelerated carbonation on cementitious roofing tiles reinforced with lignocellulosic fibre, Constr. Build. Mater. 24 (2010) 93-201.
[33] R. Valle-Zermeño, J.E. Aubert, A. Laborel-Préneron, J. Formosa, J.M. Chimenos, Preliminary study of the mechanical and hygrothermal properties of hemp-magnesium phosphate cements, Constr. Build. Mater. 105 (2016) 62-68.

[34] Z. Zhang, D. Huisingh, Carbon dioxide storage schemes: Technology, assessment and development, J. Cleaner Prod. 142 (2017) 1055-1064. 